\title{
Learning via Website for Teachers and Students
}

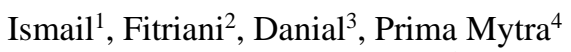 \\ \{fitrianifitri240@gmail.com² \\ Tarbiyah and Teacher Training, Islamic Institut of Muhammadiyah Sinjai, Indonesia ${ }^{1,2,3,4}$
}

\begin{abstract}
Conventional education systems should be innovated by utilizing information technology. The use of books has been replaced by e-books, blogs and websites as learning resources and can be accessed anywhere and anytime. Moreover, learning during this pandemic requires teachers and students to use various online facilities such as websites. The purpose research is to provide training in the manufacture and use of web-based learning media and to describe the effectiveness of web-based learning media for teachers and students. This research uses research action research. In the process of the research action cycle, each cycle consists of four stages, namely problem diagnosis, action planning, action implementation, and action evaluation. The results of the n-gain analysis obtained the value of $g=0.55$ by teacher and $g=0.57$ by students. Based on the table of the n-gain criteria, the value is in the Medium category. The conclusion is that there is an increase in learning achievement after the use of web-based learning media in the learning process. Based on the research results, it was found that the Learning Via Website for Teachers and Students was very effective in use.
\end{abstract}

Keywords: Learning, websites, teachers, students

\section{Introduction}

Learning in the current Pandemic era encourages all forms of face-to-face learning to become non-face-to-face or commonly known as online learning. Face-to-face learning certainly requires learning facilities that require internet access. Internet-based learning has replaced the use of books as printed media with the existence of e-books, blogs or websites (web) as learning resources consisting of various writings that can be accessed anywhere and anytime. This of course can support a learning that can take place anywhere and anytime without being hindered by time and place. In addition, the use of internet technology for students can be used as a medium for discussion between teachers and students without having to be constrained by distance so that effective learning can be created in a non-formal atmosphere.

Along with the development of the internet today, there have been many sites that are not relevant to learning. The existence of various sites that are illegal, raise negative issues and can plunge students into negative things. Therefore, the role of teachers as educators is very important in guiding and directing students to select and sort information that is useful for learning. To avoid wasting the time used in accessing information that is believed to be irrelevant in learning, teachers need to prepare web-based learning media that have been packaged in such a way that learning can take place effectively and efficiently with the provided web address. Website or site is a collection of pages of information on the internet about a particular subject published by a person or organization and usually consists of fanfare, video and sound [1]. The actual website on the internet is written as www (world wide web) but 
sometimes most people abbreviate the website or www to just web. Web-based learning is a teaching and learning process that is carried out by utilizing the internet network, so it is often referred to as e-learning. Web-based learning is learning that utilizes the attributes and resources of the World Wide Web (Web) to create a conducive learning environment. With the existence of a web that can be used by all groups, especially students and educators, it can facilitate learning anywhere and anytime even though it is a long distance. Learning using the web, students and teachers, view study schedules, send assignments, view grades, consult, and even conduct discussions.

The development of learning designs for the web is designed in such a way that the online learning process can run effectively. There are three main elements that must be present in webbased learning design, namely learning tasks, learning resources, and learning supports. Learning tasks include activities, problems, and interactions to engage students. Learning resources contain content, information and resources that can be accessed by students. Learning supports related to learning instructions, motivation, feedback, and easy access for students.

Responding to the importance of using web-based learning media, teachers of course must have knowledge about the use of web-based learning. However, the reality that occurs in the field is still minimal knowledge of the use of web-based learning media. The awareness of the importance of using instructional media is still neglected by teachers for various reasons. Limitations in learning how to use learning media, availability of preparing appropriate learning media and limited funds are the basic reasons for teachers to take advantage of this web-based learning facility. Moreover, if the school is far from the city center, teachers still lack knowledge and use of learning media, especially web-based.

Based on the results of observations by researchers at the MTs Muhammadiyah school, Sinjai Regency, which is a school that is familiar to researchers, it seems that teachers still lack knowledge of the creation and use of the web as a learning medium. Even of the 16 teachers who actively teach at the school, only two are able to use the web. Even worse, there are some teachers who don't even know about using the internet as a learning medium. The internet is understood to be limited to a communication medium such as WhatsApp and Facebook. Even though the teachers are aware of their shortcomings, the limited time for self-taught learning about the use of web-based learning is their obstacle. Therefore, the researcher views the need to conduct a learning training via website for teachers and students at MTs Muhammadiyah Sinjai Regency. Learning via the website by researchers includes training on the creation and use of learning media via the website which is divided into training for teachers and students.

The results of previous research conducted by Mahendra Adhi Nugroho et al, showed that training in making web blogs was very useful for them as educators. They feel the need to develop web-blog-based learning media as a medium for conveying learning messages. This media can help educators integrate online and face-to-face (conventional) learning so that it can complement each other. It also provides new learning experiences for students so that the teaching and learning process can be more varied and innovative [1]. In addition, the results of research by Muhammad Taufik, et al. Show that community service activities in the form of Web-based Learning Media Making Training for Science Teachers are very useful for participants because they can add insight into knowledge and skills in making Web-based learning media [2].

Hesti Lukitaningrum, who researched a web-based learning media product with the address http://www.databaseforsmk.com. Products are assessed from aspects of software, aspects of learning media and aspects of visual communication. The learning media databaseforsmk.com contains database material with sub-material about knowing MySQL and installing MySQL. The application offers multimedia facilities with a combination of text, images and videos. 
Based on the tests carried out, the development of learning media on database material in Vocational High School class XI as a whole in the aspects of software engineering, learning media and visual communication can be categorized as feasible, so that this learning media can be used as a learning medium to assist the learning process [3]. Hamonangan Tambunan added with the results of the research showing that website-based learning in the electrical machine management course is very efficient in contributing to the learning process. Learning can be accessed openly with the availability of material search facilities, discussion forum facilities, and active contributions (comments) and fulfilling the evaluation process so that it can be seen the level of student mastery of learning materials [4]. He also added that I Gede Mahendra Darmawiguna and Made Windu Antara Kesiman with the results of the research showed that students gave very positive and balanced responses to the learning media developed. Based on the calculation of the results of the responses based on the statements, it is found that the average student response falls into the positive category [4].

Based on the description above, the researcher intends to provide a training for the making and utilization of learning via WEB for teachers and students at MTs Muhammadiyah, Sinjai Regency. The selection of the research location chosen by the researchers was based on the lack of knowledge of teachers and students in the school regarding the creation and use of web-based learning.

\section{Method}

This research was conducted at MTs Muhammadiyah in Sinjai Regency which is located at JL. Sultan Hasanuddin No. 20, Sinjai Regency, South Sulawesi. This research uses action research research. In Indonesian, action research is translated as "action research", but there is also a mention of "action research". In the process of the action research cycle, each cycle consists of four stages, namely problem diagnosis (diagnosing), action planning (action planning), action taking (action taking), and evaluating action (evaluating action) [6]. The picture of the action research design can be seen in Figure 1 below.

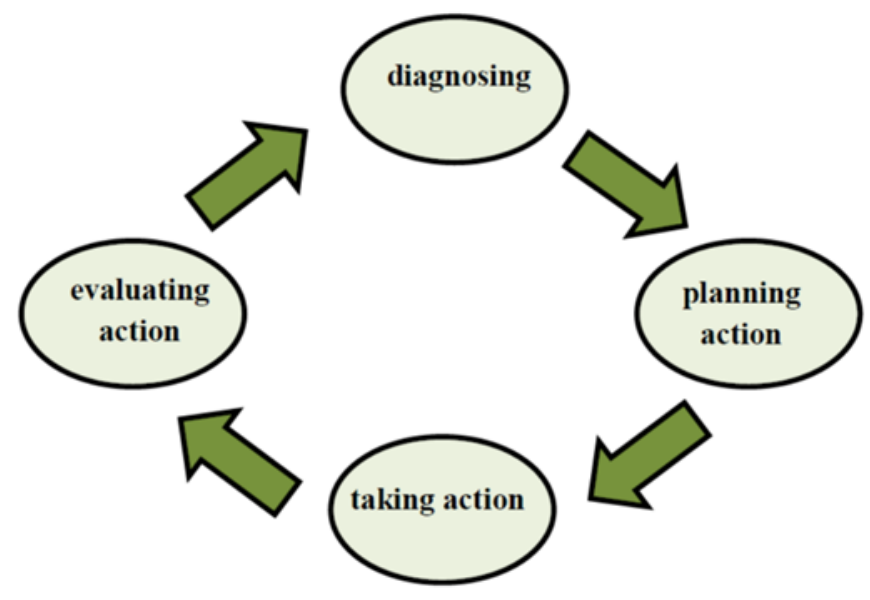

Fig. 1. Action research design 
- Diagnosing the problem (diagnosing), at the problem diagnosis stage the researcher analyzes the initial abilities of teachers and students by giving a pretest. This is done to find out the extent to which teachers and students are capable of related websites.

- Action planning, at the action planning stage the researcher designed a schedule for the implementation of activities, designed training materials, and designed a product in the form of a website usage guidebook.

- Taking action, at this stage the researcher provides material on the use of websites, training in making emails and websites.

- Evaluating action, at this stage the researcher evaluates the final ability of the teacher and students by giving posttests to both of them.

Sources of data in this study were obtained from the ability instruments given to teachers and students before (pretest) and after (posttest) research at MTs Muhammadiyah Sinjai Regency. The instrument used was a questionnaire instrument using a Likert scale. The techniques and methods of extracting data in this study are the methods used in collecting and managing research data which consists of observation, questionnaire, and documentation.

The data obtained in this study were analyzed based on the measured aspects. The data analysis technique is proposed based on the stages in this research. Needs analysis stage, the data analysis technique used in the needs analysis stage is descriptive qualitative analysis, which is to provide conclusions from the interview data. Development stage, the data analysis technique used at the development stage of the guide book and website uses two techniques, namely find the average and finding the average total validator's assessment. Validity is determined by matching the average total validity of all assessment items.

The criteria used to decide that the media used has an adequate degree of validity are: (1) total average value $(\bar{X})$ for all minimal aspects in the sufficiently valid category, and (2) score $\bar{A}_{i}$ for every minimum aspect in the valid category [5].

\subsection{Experimental stage}

To find out the effectiveness of learning via the website before and after training, it can be calculated using the $\mathrm{N}$-gain equation with formula as follow and as described in Table 2 .

$$
g=\frac{S_{\text {post }}-S_{\text {pre }}}{S_{\text {maks }}-S_{\text {pre }}}
$$

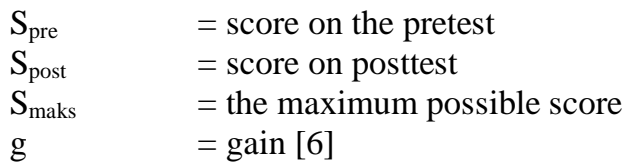

Table 2. Criteria for N-Gain Level

\begin{tabular}{ll}
\hline Average & Criteria \\
\hline $\mathrm{g}>0,7$ & High \\
$0,3 \leq \mathrm{g} \leq 0,7$ & Medium \\
$0 \leq \mathrm{g}<0,3$ & Law \\
$\mathrm{g} \leq 0$ & Failed \\
\hline
\end{tabular}




\section{Results and Discussion}

\subsection{Presenting the results}

The presentation of the research results below is divided into three presentations, namely the creation, use and assessment of the effectiveness of learning via the website for teachers and students.

\subsubsection{Creating learning media via the website}

\subsubsection{Problem diagnosis (diagnosing)}

Based on the results of discussions with teachers and students at MTs Muhammadiyah Sinjai, Sinjai Regency, it provides information that website-based learning has never been done by teachers at the school. Besides that, students have not been guided by the teacher in selecting and sorting websites that can be used as teaching materials that can support student academic achievement. In fact, most students at MTs Muhammadiyah Sinjai already have social media that can support their academic achievements.

In addition, based on the results of the analysis of the pretest instrument, the ability to manage the teachers' website with the ability criteria used as described in Table 3.

Table 3. Capability criteria

\begin{tabular}{cll}
\hline Rating Score & Average Score & Criteria \\
\hline 5 & $4,5 \leq \mathrm{X} \leq 5$ & Very Expert \\
4 & $3,5 \leq \mathrm{X}<4,5$ & Expert \\
3 & $2,5 \leq \mathrm{X}<3,5$ & Quite an expert \\
2 & $1,5 \leq \mathrm{X}<2,5$ & Less Expert \\
1 & $\mathrm{X}<1,5$ & No expert \\
\hline
\end{tabular}

On the results of the research instrument sheet, the following pretest results were obtained used as described in Table 4.

Table 4. Website Management Ability Pretest Results

\begin{tabular}{clcc}
\hline Manager & $\begin{array}{l}\text { Management } \\
\text { Capability }\end{array}$ & Average value $(\overline{\boldsymbol{X}})$ & information \\
\hline Teacher & Email & 3,16 & Very expert \\
& Website & 1,5 & Less expert \\
Student & Email & 3,16 & Very expert \\
& Website & 1,5 & Less expert \\
\hline
\end{tabular}

So it can be concluded that website-based learning is still very minimal known by teachers and students at school of MTs Muhammadiyah Sinjai.

\subsubsection{Planning action}

The stages in action planning are as follows: 
- Designing a training schedule, at the planning stage the schedule is carried out with the researcher by discussing matching the schedule of the researcher with the principal and teachers at the school.

- Installation of school wifi, at this stage the researcher installs wifi in schools for training needs.

- Designing training materials, at the stage of planning the material the researcher then reviews the teaching material that is being and will be taught by the teacher to students in each subject matter in each batch. At this stage the researcher informs each subject teacher to prepare learning materials which will then be uploaded on the classroom learning website. So that every teacher from grade 1 to 3 prepares their teaching materials.

- Designing a product (Website Usage Guide Module), at the stage of designing the module the researcher prepares a teaching material module which contains the stages of making and using the website as a teaching medium.

\subsubsection{Taking action}

At this stage of the implementation of this action the researcher carried out training for teachers and students at MTs Muhammadiyah Sinjai. The training stages are as follows:

- Opening of the training, at this stage the researcher and the principal open a training website with the teacher and student representatives. The principal then officially opened the training.

- Teacher and student training activities, at this stage the researcher trains teachers to create websites by first dividing the jobs of each admin who manages the website that has been made.

\subsubsection{Evaluating action}

At this stage, an action evaluation will be carried out by providing a postest to the participants to find out the progress of the training before and after the training. The post-test questionnaire has not been distributed to participants since the training is still ongoing.

\subsubsection{Using learning media via website}

The stages of training for web-based learning media are as follows:

- Making an e-mail for website registration, at this stage each admin creates an e-mail for website registration.

- Purchasing Hosting and Domains, at this stage each admin buys a domain and hosting on the Niagahoster page by first logging in using the e-mail that has been created.

- Setting up the website, at this stage each admin sets up the website that has been created by adding menus and submenus according to the needs of the website content. Adding menus and submenus can be done by clicking View $\rightarrow$ add menu item $\rightarrow$ add menu $\rightarrow$ save menu.

- Managing the website by applying teaching materials, at this stage each admin uploads / posts the files needed for website-based learning. 


\subsubsection{The effectiveness of learning via the website in terms of teacher and student competencies}

In the analysis stage, the effectiveness of web-based learning in terms of the competence of teachers and students at MTs Muhammadiyah Sinjai was carried out with 2 stages of analysis. The stage of the analysis consists of analyzing the effectiveness of web-based learning in terms of the competence of research teachers and secondly, analyzing the effectiveness of websitebased learning in terms of student competencies. Analysis of the effectiveness of web-based learning is carried out by providing a questionnaire instrument to the training participants before (pretest) and after (postest) training. The questionnaire instrument grid is described as in Table 5.

Table 5. Web-Based Learning Pretest Postest Grid

\begin{tabular}{lll}
\hline Aspect & Indicator & Question \\
\hline e-mail & E-mail creation & How capable are you in composing e-mail? \\
& open e-mail & How are you able to open e-mails? \\
& Send -mail & What is your ability to send e-mail? \\
replay -mail & How are you able to reply to (replay) incoming e-mail? \\
forward -mail & What is your ability to forward e-mail? \\
Browsing & How is your ability to browse the website? \\
Register & How is your ability to create a website? \\
& Domain & How are you able to create a website Domain? \\
& Hosting & How are you capable of creating website hosting? \\
& SSL & How is your ability to create a website SSL? \\
& Post Writing & How is your ability to post articles on the website? \\
& Post pictures & How is your ability to post images on the website? \\
& Post videos & How is your ability to post videos on the website? \\
& Post editing & How are your skills in website post editing? \\
& Create page & How is your ability to create website pages? \\
& Install plugins & What is your ability to install website plugins? \\
\hline
\end{tabular}

The results of the analysis of the effectiveness of website-based learning in terms of teacher and student competencies can be calculated using the following formula.

$$
g=\frac{S_{\text {post }}-S_{\text {pre }}}{S_{\text {maks }}-S_{\text {pre }}}
$$

$$
\begin{array}{ll}
\mathrm{S}_{\text {pre }} & =\text { score on the pretest } \\
\mathrm{S}_{\text {post }} & =\text { score on the postest } \\
\mathrm{S}_{\text {maks }} & =\text { the maximum possible score } \\
\mathrm{g} & =\text { gain } \\
\mathrm{g} & =\frac{884-498}{1200-498} \\
\mathrm{~g} & =\frac{386}{702} \\
\mathrm{~g} & =0,55
\end{array}
$$

Based on the n-gain criteria table, the pretest-posttest results are in the Medium category. So it can be concluded that there has been an increase after the use of web-based learning media 
in the learning process carried out by the teacher. The analysis of the effectiveness of websitebased learning in terms of student competencies can be seen from the following calculations.

$$
\begin{aligned}
& \mathrm{g}=\frac{575-270}{800-270} \\
& \mathrm{~g}=\frac{305}{530} \\
& \mathrm{~g}=0,57
\end{aligned}
$$

Based on the n-gain criteria table, the pretest-posttest results are in the Medium category. So it can be concluded that there has been an increase after the use of web-based learning media in the learning process carried out by students.

\subsection{Discussion}

Learning via the website which is carried out with a series of training activities for teachers and students at Mts Muhammadiyah, Sinjai Regency consists of two main activities, namely creating a website and using the website. This activity begins with the delivery of the activity plan, then continues with the delivery of training and practical materials.

The training activity begins with the delivery of material. After the delivery of the material, the training activity ended with the distribution of the participant's Instrument Sheet for the implementation of the training that had been followed. The purpose of distributing this instrument is to obtain an overview of the participants' opinions on the training, both material and potential for application in learning

Based on the activity participant response questionnaire, information on the material presented was interesting, because website-based learning media were new to teachers; service activities like this should be used as routine activities with different material and a longer duration; This activity provides benefits and inspires participants to develop competencies in making innovative learning media.

The implementation of this training is supported by various factors. Spread invitations to the implementation of training through the executive committee, so as to facilitate the delivery of information on the training implementation agenda; Participants have a high interest in the material presented which can be seen in the enthusiasm of the participants during the training activities; the training venue is conditioned in each room of the school building and activates whatsapp discussions for coordination of unknown matters. In addition, the participants already know the location of the training, making it easier for participants to go to the location. On the other hand, the implementation of this training activity also faced several obstacles, namely dense material with a limited time allocation and the low variation in IT capabilities of the participants.

The research results obtained that learning through the website for teachers and students is very effective to use, besides that learning websites can support the competence of teachers and students at MTs Muhammadiyah Sinjai Regency. The results obtained are in line with previous research conducted by Erwin Januarisman and Anik Ghufron with a study of the development of web-based learning media, which resulted in an increase in student achievement through learning via the website [7]. Also added to the results of Fariza Rohdiani and Lusia Rakhmawati concluded that web-based learning can also be used as a supporting tool in the learning process with a percentage of validity up to $83 \%$ [8]. In addition, Kiki Aryaningrum's research found that web-based learning (e-learning) had an effect on student learning outcomes by $36 \%$ [9]. 


\section{Conclusion}

Learning via the website for teachers and students is very effective to use, especially during the current pandemic. Website-based learning activities carried out with training conducted by researchers also greatly support the competence of teachers and students at MTs Muhammadiyah, Sinjai Regency.

\section{Acknowledgements}

During the writing of this article the author is very grateful to the Research of the Ministry of Religion of the Republic of Indonesia as a research fund contributor, to the Teachers and Staff of MTs Muhammadiyah Sinjai, and students who were directly or indirectly involved during the research. Thank you to the Muhammadiyah Sinjai Islamic Institute as a forum for writers to work.

\section{References}

[1] M. A. Nugroho, M. A. Fajar, P. W. Dewanti, R. I. Aghni, and M. N. N. Siregar, "Pelatihan Pembuatan Media Pembelajaran Berbasis Web Blog Dan Aplikasi Android Bagi Guru SMK," 2016.

[2] H. Muhammad Taufik, Sutrio, Syahrial A, Hairunnisyah Sahidu, "Pelatihan Media Pembelajaran Berbasis WEB Kepada Guru IPA SMP Kota Mataram,” J. Pendidik. dan Pengabdi. Masy., vol. 1, no. 1, pp. 77-81, 2018.

[3] H. Lukitaningrum, "Pengembangan Media Pembelajaran Brbasis WEB Pada Materi Basis Data Di Sekolah Menengah Kejuruan Kelas XI," 2016.

[4] M. W. A. K. I Gede Mahendra Darmawiguna, "Media Pembelajaran Berbasis WEB Dan Flash Untuk Mata Kuliah Riset Operasi di Jurusan PTI, Undiksha,” J. Sains dan Teknol., vol. 2, no. 1, pp. 128-138, 2013.

[5] Nurdin, "Model Pembelajaran Matematika yang Menumbuhkan Kemampuan Metakognitif untuk Menguasai Bahan Ajar," 2007.

[6] E. \& Casey, Research Methods in Education. New York: Wadsworth Pub.Co, 1982.

[7] E. Januarisman and A. Ghufron, "Pengembangan Media Pembelajaran Berbasis Web Mata Pelajaran Ilmu Pengetahuan Alam Untuk Siswa Kelas Vii,” J. Inov. Teknol. Pendidik., vol. 3, no. 2, p. 166, 2016.

[8] F. Rohdiani and L. Rakhmawati, "Pengembangan Pembelajaran Berbasis Web Pada Mata Pelajaran Dasar Elektronika di SMK Negeri 3 Jombang,” J. Pendidik. Tek. Elektro, vol. 6, no. 1, pp. 105-110, 2017.

[9] Kiki Aryaningrum, "Pengaruh Pembelajaran Berbasis Web (E-Learning) Terhadap Hasil Belajar Siswa Pada Mata Pelajaran Geografi Kelas Xi Di Sma Negeri 9 Palembang,” J. Penelit. dalam Bid. Pendidik. dan Pengajaran, vol. 10, no. 2, pp. 154-162, 2016. 